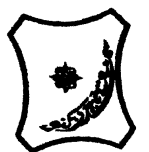

Bayero Journal of Pure and Applied Sciences, 10(2): 115 - 121

Received: October, 2017

Accepted: December, 2017

ISSN $2006-6996$

\title{
SPATIO-TEMPORAL TRENDS OF TYPHOID FEVER AMONG YOUTHS ATTENDING MUHAMMAD ABDULLAHI WASE SPECIALIST HOSPITAL IN KANO METROPOLIS, NIGERIA
}

\author{
Ishaq A. Abdulkarim and Murtala U. Mohammed \\ Department of Geography, Bayero University, Kano \\ *Correspondence author: iaaliyu.geo@buk.edu.ng
}

\begin{abstract}
Typhoid fever continues to be significant causes of illness and death particularly among children and adolescents in developing countries as a result of poor sanitation and unsafe food and water supply especially where the water is contaminated by human feces. This study analysed the spatial and temporal trends of typhoid fever in Kano metropolis between 2010-2014. Hospital records for youths attending Muhammad Abdullahi Wase Specialist Hospital (MAWSH) were used. Coordinate of wards in the metropolis was also generated and imported into Arc GIS environment. G-Statistics was used to determine the distribution and cluster of typhoid prevalence. The results showed an upward trend with increase in age. It also showed a downward trend from 2010 to 2014, indicating that people are becoming aware of the disease and the predisposing factors. The findings also revealed higher prevalence among the males. The results of the G-Statistics showed higher prevalence in the northern part of the metropolis, with hot spots in Dakata and Tarauni wards. The study recommends frequent vaccination and good eating and drinking habits as well as good hygienic practices at home and outside home as remedies for addressing the problem.
\end{abstract}

Key Words: Typhoid Fever, Spatial, Temporal, Youths, G-statistics, Kano.

\section{INTRODUCTION}

Typhoid fever is becoming a major health problem in developing countries (Adhikari et al, 2015) as a result of poor sanitation and unsafe food and water supply especially where the water is contaminated by human feces (Okafor 2007; Crump and Mintz, 2010) and consuming raw milk products, flavored drinks and icecreams (Marathe et al, 2012). It is caused by Salmonella typhi, (Cheng et al, 2013) a Gramnegative bacterium (Manangazira et al, 2011). It is a severe systemic illness characterized by fever and abdominal pain (Parikh, 2012), found only in man (Kalra et al, 2003; Ifeanyi, 2014), and has the ability to survive for several months in soil and water (Tran et al, 2005).

In areas where typhoid fever is endemic, the incidence peaks in the youngest age group of 1-19 years (Lin et al., 2000). Acute cases have been identified more in adolescents and adults in the age group of 15-24 years (Acute Communicable Disease Control, 2005). However, the highest burden of the disease especially in developing countries has been observed in children of school age (Sharma et al 2003; Al-ameri and Saif, 2014). Cochrane Nigeria (2014) opined that school age children and adults are mainly affected. Though in some areas, incidence rates among preschool children (below 5 years) are similar to those of school age children.

Flying insects such as flies feeding on feces may sometimes transfer the bacteria through poor hygiene habits and sanitation conditions. Other carriers may be out there working as food handlers, food processors in food or water industries and also household workers who take care of daily meals and feeding (Udeze et al, 2010; Ifeanyi, 2014). Community-level risk factors include population density, temperature, rainfall, river level and proximity to water sources (Crump and Mintz 2010).

Though typhoid cases are observed throughout the year (Singh, 2001), the peak incidence of typhoid fever is reported during summer in endemic areas, a period that coincides with the rainy season characterized by low river levels (Alajeely, et al., 2014; Lin, et al., 2000; Luxemburger, 2001) and a substantial increase in fly population (Singh, 2001). Benjamin (2002), in his study reported peaks in the dry season (December) coinciding with low water supply period and in May which is the begging of the rainy season when contaminated water is spread by rains.

The distribution of typhoid fever in Nigeria seems uncertain and appears to show variation (Udeze 2010). Some studies showed high prevalence in females (Modebe et al., 2014, Omogunloye 2013; Udeze 2010, Ibegbulam et al., 2013 Uttah et al, 2013), some observed high prevalence in males (Okonko et al, 2010 Seljul et al 2014) and some observed no difference among the sexes (Opara et al, 2011: Onyindo et al., 2014).

There is also uncertainty in the distribution among the age groups. Ibegbulam-Njoku, Chijioke-Osuji and Duru (2014) observed high prevalence among people aged 26-35years. This is line with earlier study by Isa, el al (2013) who reported high cases for patients 1324 and 25-46years, some observed high prevalence among children aged 0-5years and 13-24years (Ifeanyi 2014; Isa el al2013; Uttah et al., 2013). 
It is evident from previous studies that youths are among the most infected which could in turn affect the economy of the state since they are the most active group of the population. This study therefore investigated the spatial and temporal distribution of typhoid fever among the youths attending Muhammad Abdullahi Wase Specialist Hospital (MAWSH) in Kano Metropolis, Nigeria.

\section{STUDY METHODS}

\section{Study Area}

The study area which is Kano metropolis, lies between latitude $11^{0} 50^{\prime}$ to $12^{\circ} 07^{\prime} \mathrm{N}$ and longitude $8^{0} 22^{\prime}$ to $8^{0} 47^{\prime} \mathrm{E}$ and altitude 472 meters above sea level
(Figure 1). The climate of the area is tropical wet and dry climate, coded Aw by the Koppen's Climatic Classification System (Olofin, 1987). Kano metropolis is bordered by Minjibir LGA to the northeast and Gezawa LGA to the east, Dawakin Kudu LGA to the south east and Madobi and Tofa LGAs to the south west.

The study area includes the eight metropolitan local government of Kano State namely Dala, Fagge, Gwale, Kano Municipal, Kumbotso, Nassarawa, Ungogo, and Tarauni. The population of the Kano Metropolis based on 2006 is 2,826,307 (National Population Commission, 2006).

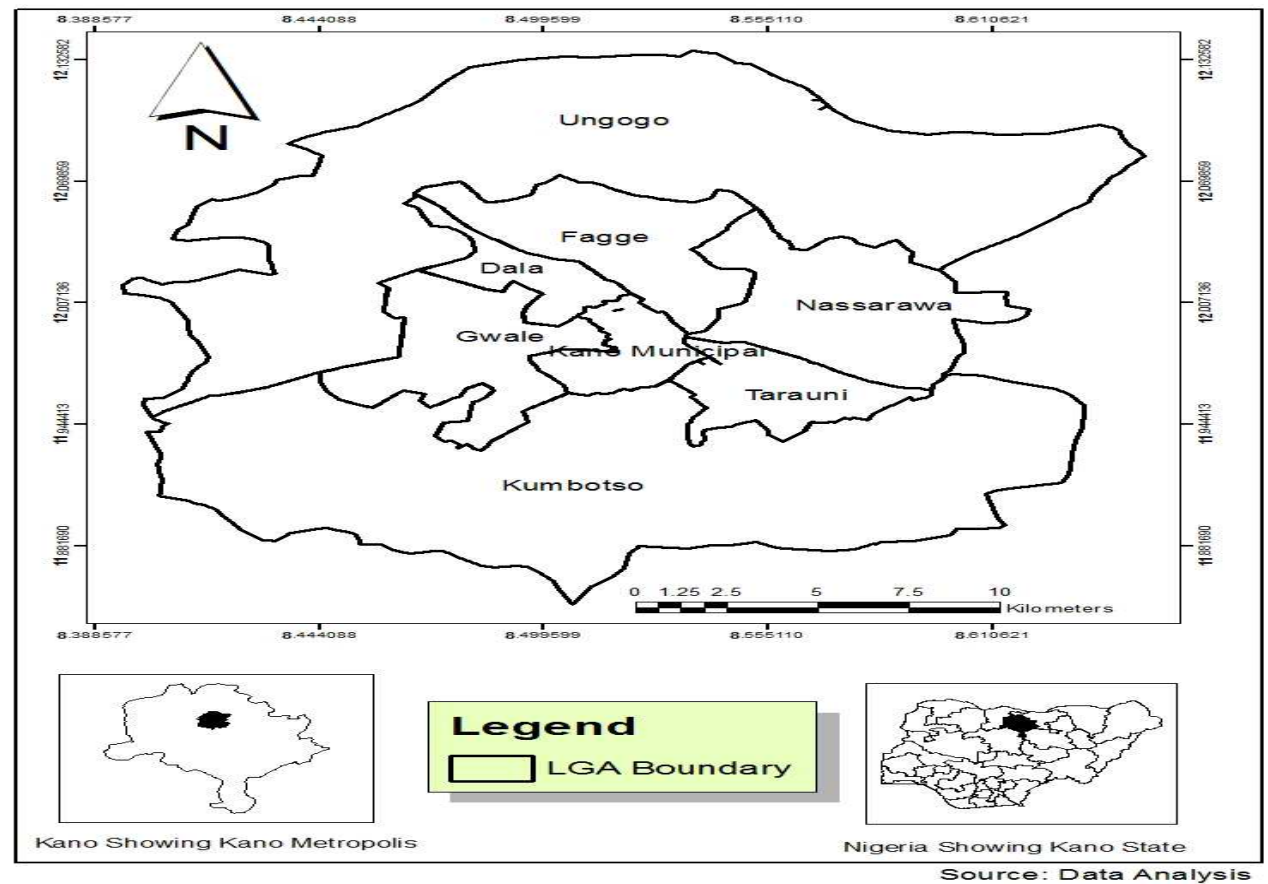

Figure 1: Kano Metropolis

\section{Data Collection}

Hospital records of confirmed typhoid fever cases certified by the Head of Records Department of Muhammad Abdullahi Wase Specialist Hospital (MAWSH) were used for the study. The record is only for youths aged 15-24years (United Nation, 2001). Case files of patients were consulted and details such as age of patients, address and patients' condition on discharge (treated, absconded, referred or dead) were derived and recorded in Microsoft excel. Coordinates of wards in the metropolis were also generated from Google Earth and imported into Arc GIS environment.

\section{Data Analysis}

Data recorded of typhoid for the period of five years (2010-2015) were imported into Arc IS environment for the analysis. G-Statistics was used to determine the distribution and cluster of the typhoid fever prevalence. Different symbolization methods were used to prepare the final map. Trend analyses were performed in the Microsoft Excel environment to find out the temporal nature of the disease. The final outputs were displayed as maps and charts.

\section{RESULTS AND DISCUSSION}

The study showed that the prevalence of typhoid fever among youths attending MAWSH, Kano rose as the age of the patients (youths) increased and peaked at the age of 20years. However, the prevalence of the disease started to fall after the age of 20years (Figure 2 ). The general trends of the disease showed increases in the infection with age (Figure 3). The result showed that students were the most infected among the youths attending the hospital accounting for over $50 \%$ of the reported cases. The proportion of businessmen and housewives is quite noteworthy (Figure 4). The high prevalence among students and those in business might be connected to eating outside, while that of the housewives might be connected to personal hygiene, since they are the care givers and food handlers in their houses. In most cases, the youths recovered from the disease. 
However, a little over $2 \%$ of the youths died of the disease and less than $1 \%$ were transferred or referred to tertiary healthcare facility (Table 1 ). The deaths recorded might be connected to late report of the patient at the hospital when the disease reached complicated stage. This happens when people engage in self-medication and the practice of not going for diagnosis before treatment. It might also be associated with the socioeconomic status of the parents or youths.

The yearly trends showed general decline in the prevalence of the disease among youths attending the

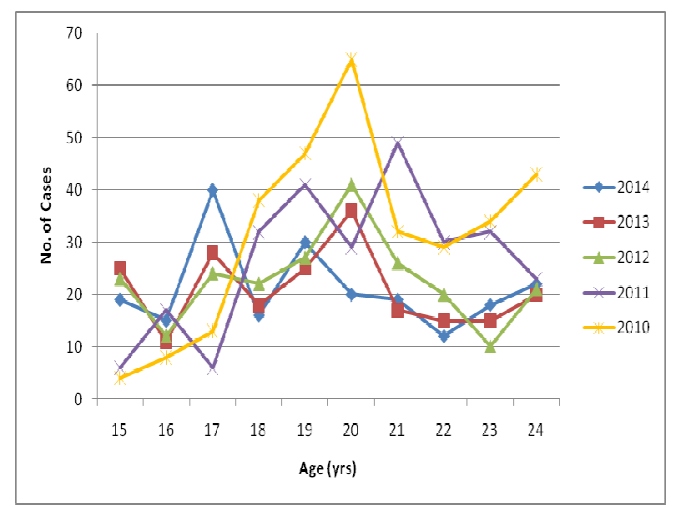

Fig. 2: Age of youth with typhoid fever

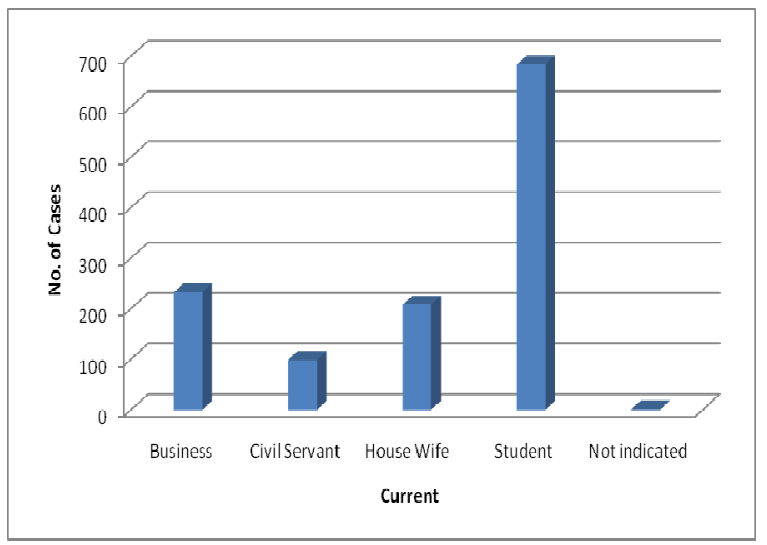

Fig 4: Occupations of youths infected with typhoid

Table 1: Status of youths after discharge from hospital

\begin{tabular}{lcccccccccccc}
\hline \hline \multirow{2}{*}{$\begin{array}{c}\text { Condition on } \\
\text { Discharge }\end{array}$} & \multicolumn{2}{c}{2014} & \multicolumn{2}{c}{2013} & \multicolumn{2}{c}{2012} & \multicolumn{2}{c}{2011} & \multicolumn{2}{c}{2010} & \multicolumn{2}{c}{ Total } \\
\cline { 2 - 13 } & $\mathrm{F}$ & $\%$ & $\mathrm{~F}$ & $\%$ & $\mathrm{~F}$ & $\%$ & $\mathrm{~F}$ & $\%$ & $\mathrm{~F}$ & $\%$ & $\mathrm{~F}$ & $\%$ \\
\hline Death & 0 & 0 & 4 & 1.9 & 9 & 4 & 5 & 1.9 & 10 & 3.2 & 28 & 2.3 \\
Recovered & 211 & 100 & 206 & 98.1 & 216 & 95.6 & 260 & 98.1 & 303 & 96.8 & 1196 & 97.6 \\
Transferred & 0 & 0 & 0 & 0 & 1 & 0.4 & 0 & 0 & 0 & 0 & 1 & 0.1 \\
\hline Total & 211 & 100 & 210 & 100 & 226 & 100 & 265 & 100 & 313 & 100 & 1225 & 100 \\
\hline \hline
\end{tabular}

hospital even though there was a slight rise in the year 2014 (Figure 5). This might be as a result of increasing awareness about the determinants of the disease. The mean temporal monthly distribution of the disease for the study period (2010-2014) showed rise in the prevalence in the month of March that later falls in the months of April, May and June. The disease peaked in the month of July and gradually dropped. The general trend however showed a uniform trend throughout the year (Figure 6).

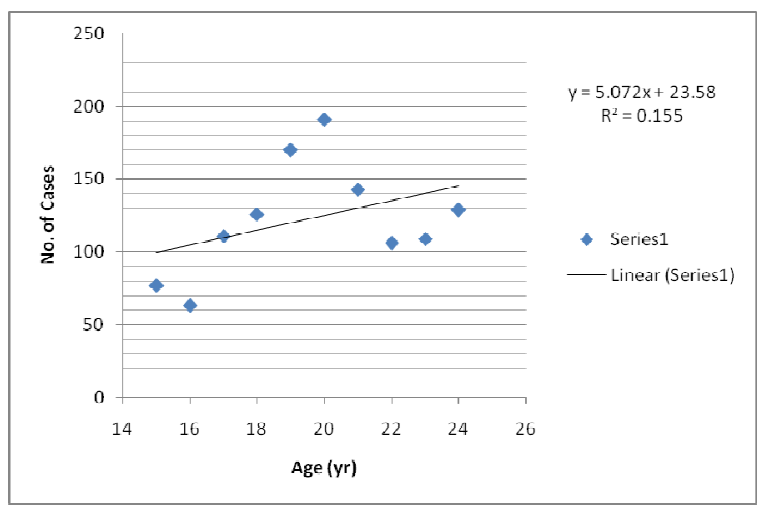

Fig 3: Age Trends of Youth with typhoid fever

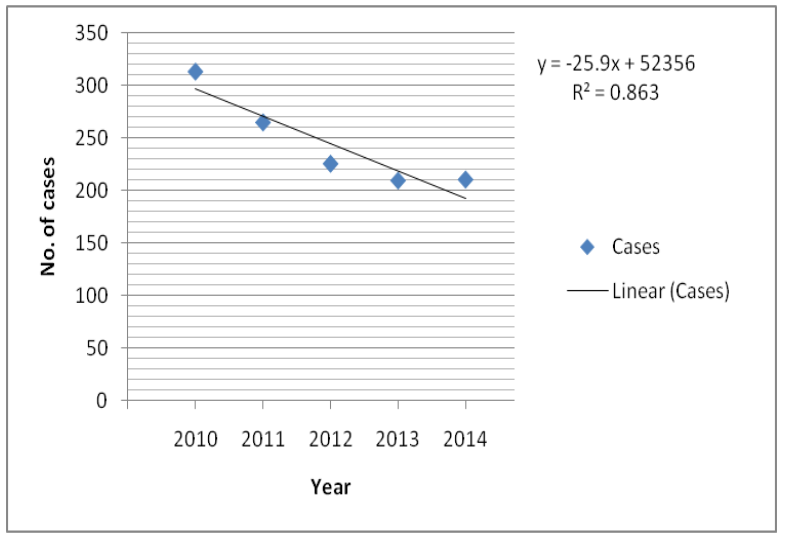

Fig. 5: Temporal trends of typhoid fever 
Bajopas Volume 10 Number 2 December, 2017

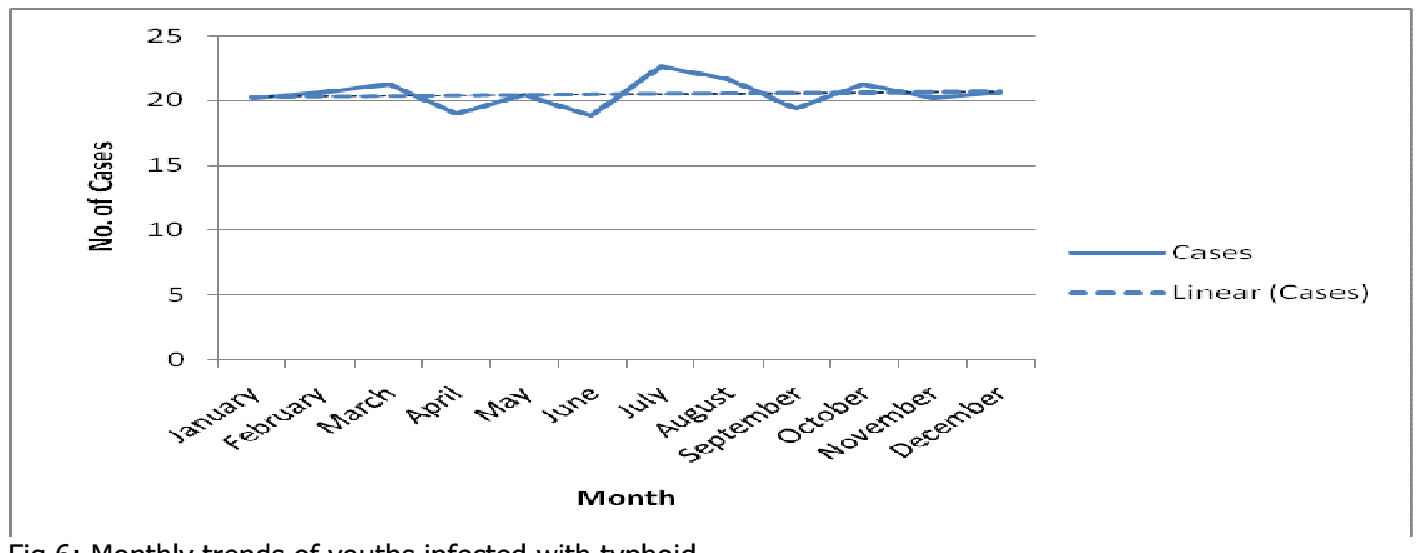

Fig 6: Monthly trends of youths infected with typhoid

The spatial distribution of typhoid fever among youths showed a high concentration in areas around Nasarawa, Tarauni and at the southern part of Fagge local government areas. A low to moderate prevalence was observed around Dala, Gwale, Kano Municipal, and Kumbotso local government (Figure 7). The Hotspot analysis results indicated cold spot of $99 \%, 95 \%$ and $90 \%$ confidence around Gwale, Kumbotso, and Ungogo respectively, and areas of no significance in Dala, Kano Municipal and part of Fagge local governments. The Hot spots of $90 \%, 95 \%$, and $99 \%$ confidence were generally observed in areas around Nasarawa, Tarauni, and southern part of Fagge. This could be attributed to the closeness of these areas to Muhammad Abdullahi Wase Specialist Hospital (Figure 8).

The nearest neighbour analysis was also conducted to

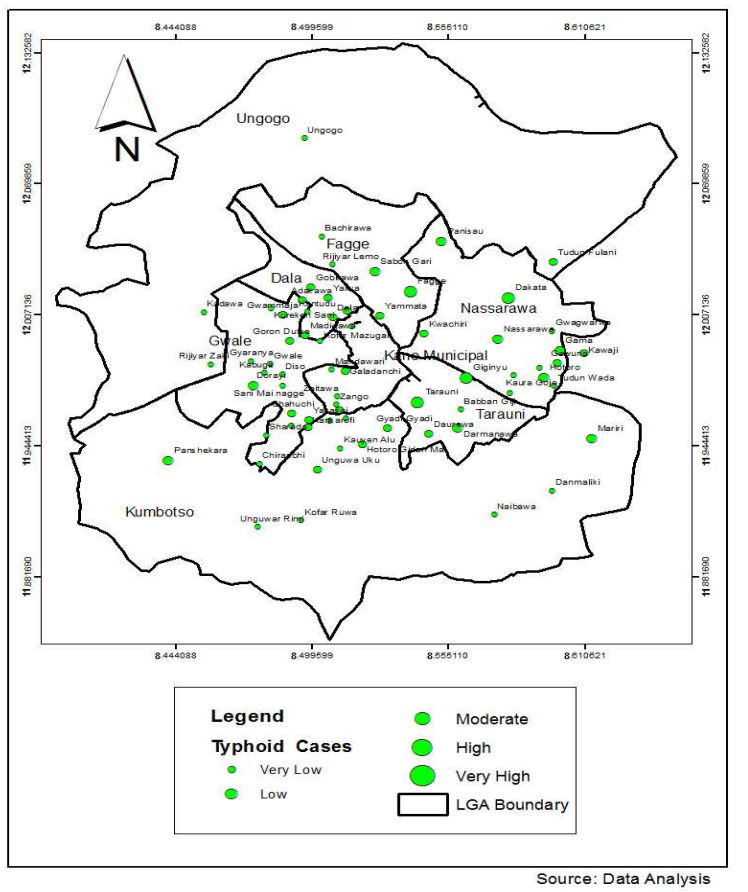

Fig 7: Distribution typhoid fever Among youth compare the observed average distance between points and their nearest neighbours, with the distance that would be expected between nearest neighbours in a random pattern. The ratio of nearest neighbour was 1.12 with p-value of 0.06 (Figure 9), indicating a near dispersed. Given the z-score of 1.196 , there was a less than $10 \%$ likelihood this dispersed pattern could be the result of random chance (figure 10). This pointed to low and near absence of clustering of the typhoid disease in the area. The observed General GStatistic z-score of -0.95 and a p-value of 0.34 indicated that the pattern did not appear to be significantly different from random at $90 \%$ level of significance. This shows that location plays insignificant role in the distribution of the disease in the area.

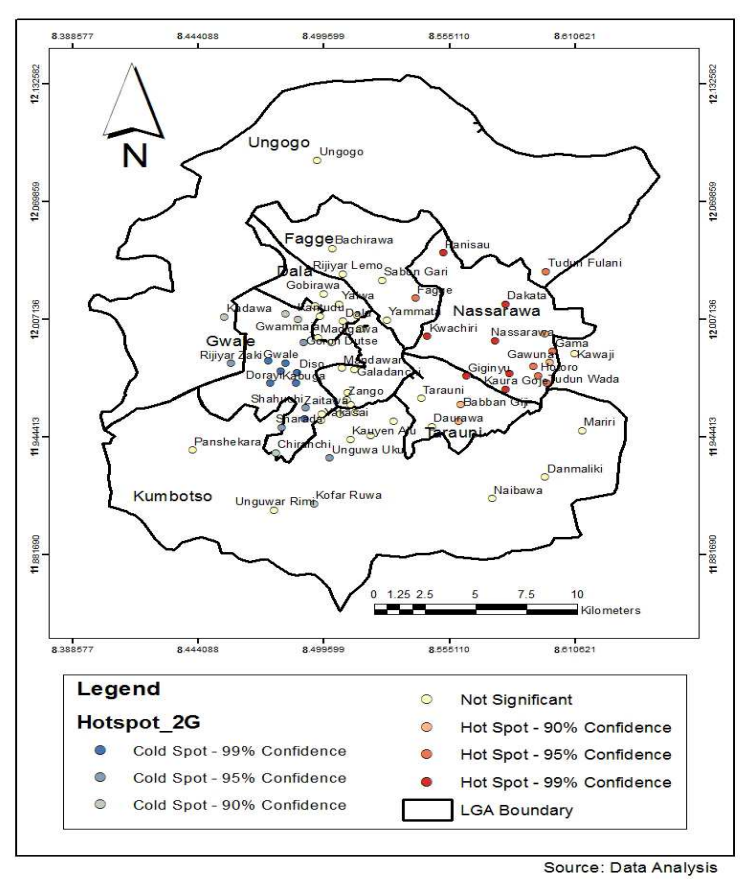

Fig. 8: Hot Spot of typhoid fever among Yourth 


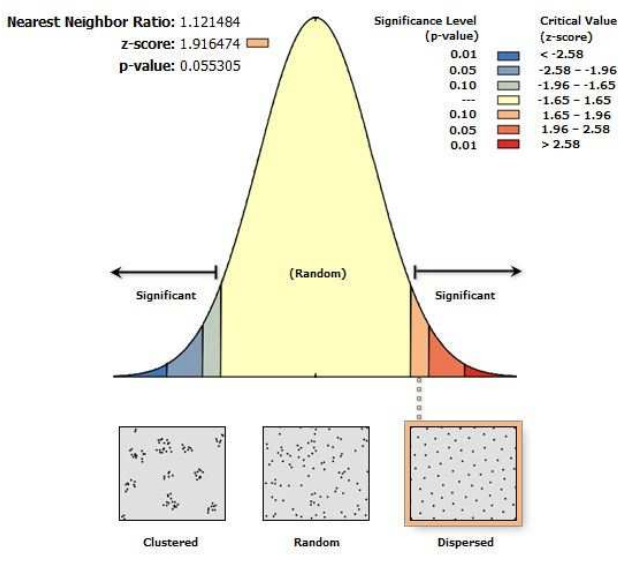

Given the $z$-score of 1.91647433086 , there is a less than $10 \%$ likelihood that this dispersed pattern could be the result of random chance.

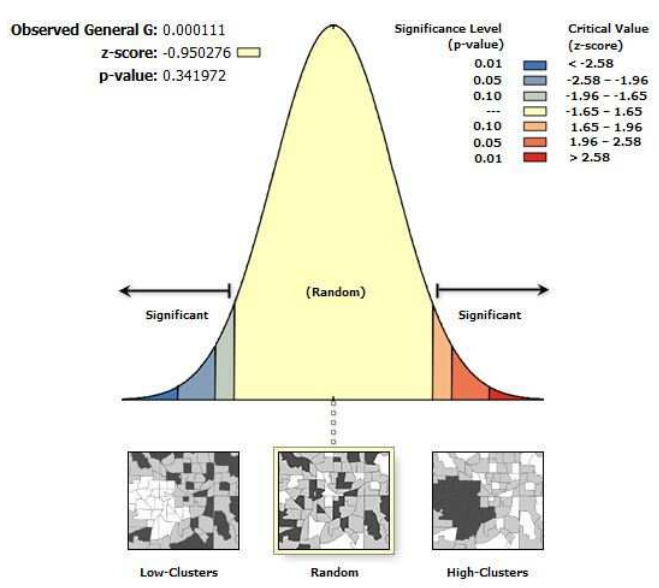

Given the $z$-score of -0.950275579711 , the pattern does not appear to be significantly different than random.
Fig. 9: Nearest neighbour Result typhoid

\section{Discussion}

This study used five years of reported typhoid data of youths attending Muhammad Abdullahi Wase Specialist Hospital in Kano Metropolis. The study showed high prevalence (1225 cases) of typhoid fever among youths in the metropolis. This agrees with ACDC (2005), who reported that acute cases have been identified more in adolescents and adults in the age group of 15-24 years. The high prevalence especially among the youths might be connected with the fact that they spend most of their time outside their homes and they consume unsafe drinking water and food from outside sources (Ibegbulam-Njoku, Chijioke-Osuji and Duru, 2014). The study also reported higher prevalence among males than females, conforming to the work of Alajeely (2014), Ekesiobi, Igbodika, and Njoku (2008), Igharo et al. (2012), Isa et al. (2013), Okonko et al. (2010) and Shuaibu, (2010). There was a serious decline in the percentage of death recorded from the reported cases (2.3\%) compared to the work of Benjamin in 2002 that showed $13.2 \%$ of the patients did not recover from the disease.

There was a gradual decline in the incidence of the disease in Kano, contrary to the findings of Benjamin (2002) that showed a rise in the incidence from 19972000 in Kano. It also showed yearly peak in the months of July and August. This agrees with the work of Abubakar (2015), and Dewan et al, (2013) who asserted that the incidence is highest in the monsoon months, and Wang et al (2013) who opined that there is a positive correlation between the prevalence of the disease and precipitation time. The spatial distribution of the disease showed high incidence Nasarawa, Tarauni,LGAs, and at the southern part of Fagge LGA. The high incidence in Fagge LGA is corroborated by the work of Abubakar (2015) which showed high prevalence among children in Kano metropolis with the disease.

\section{Conclusion}

Using five years typhoid data from Muhammad Abdullahi Wase Specialist Hospital, Kano and spatial analytical methods, this study analysed the prevalence of the disease in the Kano metropolis. The demographic characteristics of youths infected within the period under study (2010-2014) showed the prevalence rose as the age increases and peaked at the age of 20years with the male youths more infected than the females. The temporal analysis showed that there was a decline in the prevalence from 2010 to 2014, with peak prevalence in the months of July and August, and a decline in the percentage of death from $13.2 \%$ (Benjamin, 2002) to $2.3 \%$ in this study. The spatial distribution showed high incidence in Nasarawa and Tarauni,LGAs, and at the southern part of Fagge LGA. The study showed that typhoid fever is still endemic in Kano metropolis.

The study recommends that further studies should be done to understand socio-economic and environmental factors responsible for the high incidence of the disease in Kano metropolis. Studies on the cultural factors and lifestyle can also help in understanding the reason for the high incidence. The major routes of transmission of typhoid fever are through contaminated drinking water or eating food contaminated with Salmonella typhi. In order to prevent the spread of typhoid fever in Kano, sensitization programs should be initiated for the people on the danger of use of untreated water for drinking and other domestic purposes. Prevention is based on ensuring access to safe water and by promoting safe food handling practices. Health education is paramount to raise public awareness and induce behaviour change and vaccination against typhoid fever.

\section{Contribution of Authors:}

Ishaq A. Abdulkarim conceived the research and carried out all the write-ups.

Murtala U. Mohammed carried out the data analysis and interpretation.

Conflict of Interest: No conflict of interest. 


\section{REFERENCES}

Abubakar I. B. (2015). A Geographic Study of Typhoid Fever among Children in Kano Metropolis from 2008-2012. Unpublished Dissertation submitted to the Ddepartment of Geography, Bayero University, Kano. 16-30

Acute Communicable Disease Control (2005): Typhoid Fever, Acute; Annual Morbidity Report 135-136

Adhikari, A.,Rauniyar, R., Raut, P. P., Krishna Das Manandhar, K. D. and Gupta, B. P. (2015): Evaluation of sensitivity and specificity of ELISA against Widal test for typhoid diagnosis in endemic population of Kathmandu. BMC Infectious Diseases 15:523

Al-ameri G. and Saif N. (2014): A Prevalence Study of Typhoid Fever in Taiz and Al-Hodiedahcities in Yemen; British Microbiology Research Journal 4(2): 214-223

Alajeely A. A., Lawrence R, Jeyakumar E., Maurice N. G. (2014): Risk Factors of Typhoid Fever amongst Patients in the Allahabad Region, India, International Journal of Current Research 6(11): 10025-10029

Benjamin D. M. (2002): Typhoid Fever in Urban Kano: A Retrospective Survey. Unpublished Dissertation submitted to the Department of Geography, Bayero University, Kano. 23-41

Cheng, Y., Tang, F., Bao, C., Zhu, Y., Liang, Q., Hu, J., Liu, W., Wu, Y., Reilly, K. H., Shen, T., Zhao, Y., Peng, Z., Yu, R., Wang, H., Shen, H. and Chen, F. (2013): Spatial analyses of typhoid fever in Jiangsu province, People's Republic of China. Geospatial Health 7(2): 279-288.

Cochrance Nigeria (2014): Vacines for Typhoid Fever, Newsletter of the Nigerian Branch of the South African Cochrance Centre, Calabar Institute of Tropical and Diseases Research Prevention; University of Calabar Teaching Hospital. 1-8

Crump J. A. and Mintz E. D. (2010): Global trends in typhoid fever and paratyphoid fever, Clininical Infectious Diseases 50: 241-246

Dewan A.M Corner R, Hashizume M, and Ongee E.T (2013). Typhoid fever and its Association with environmental factors in Dhaka, Metropolitan Area of Bangladish: A spatial and time series approach. PLOS Neglected Tropical Diseases.7(1): 1-14

Ekesiobi, A. O., Igbodika, M. C. and Njoku, O. O. (2008): Co-Infection of Malaria and Typhoid Fever in a Tropical Community; Animal Research International 5(3): $888-891$.

Ibegbulam-Njoku P. N, Chijioke-Osuji C.C. and Duru F.C.(2014): Prevalence of antibody titre in healthy individual and enteric fever patients in Owerri, Nigeria. Journal of Public Health and Epidemiology 6(6): 192-196.

Ifeanyi A. O. E (2014): Changes in some haematological parameters in typhoid patients attending University Health Services Department of Michael Okpara University of Agriculture, Nigeria International Journal of Current
Microbiology and Applied Sciences 3 (1): 670674.

Igharo, E. A., Osazuwa, F., Ajayi, S. A., Ebueke, A. and Igbinigie, O. (2012): Dual Infection with typhoid and Malaria in Febrile Patients in Ikare Akoko, Nigeria International Journal of Tropical Medicine 7 (1); 49-52.

Isa M. A., Kubo I. I., Ismail H. Y., Allamin I. A. and Shettima A. (2013): Prevalence of salmonella agglutinins among patients attending hospitals in Biu, Borno State, Nigeria Scholars Research Library Archives of Applied Science Research 5 (1):83-87.

Kalra S. P, Bar S. M., Naithani N., Mehta S. R. and Swamy A. J. (2003): Current Trend Management of Typhoid Fever; MJAFI 2003; 59: 130-135.

Lin, F. Y., Vo, A. H., Phan, V. B., Nguyen, T. T., Bryla, D., Tran, C. T., Ha, B. K., Dang, D. T. and Robbins, J. B. (2000): The epidemiology of typhoid fever in the Dong Thap province, Mekong Delta region of Vietnam. American Journal of Tropical Medicine and Hygiene 62: 644-648.

Luxemburger C, Chau M.C, Mai N. L, Wain J, Tran T. $\mathrm{H}$, Simpson J. A et al.,. (2001): Risk factors for typhoid fever in the Mekong delta, southern Viet Nam: a case-control study. Transactions of the Royal Society of Tropical Medicine \& Hygiene 2 Indian Journal of Medical Research 117:10-12.

Manangazira, P., Glavintcheva, I., Mutukwa- Gonese, G. Bara, W., Chimbaru A. and Ameda, I. (eds) (2011): Guidelines for the Management of Typhoid Fever. World Health Organization 139

Marathe, S. A. Lahiri, A. Negi, V. D. \& Chakravortty, D. (2012): Typhoid fever \& vaccine development: a partially answered question Indian Journal of Medical Research 135: 161169

Modebe A. A., Nnachi A. U., Ukaegbu C. O., Tata N., Agah M. V., Udu-Ibiam O. E. and Nnachi I. A. (2014). Dual infections of Enteric Salmonella species with Schistosoma mansoni among Patients from Two Hospitals in Jos, Nigeria. Journal of Applied \& Environmental Microbiology 2(4): 198-20.

Okafor, A.I. (2007): Haematological alterations due to typhoid fever in Enugu Urban- Nigeria. Malaysian Journal of Microbiology, 3(2): 1922.

Okonko I.O., Soleye F.A., Eyarefe O.D., Amusan T.A., Abubakar M.J., M.J. Adeyi M.J., Ojezele M.O. and Fadeyi A. (2010): Prevalence of Salmonella typhi among Patients in Abeokuta, South-Western Nigeria. British Journal of Pharmacology and Toxicology 1(1): 6-14.

Olofin, E. A. (1987) Some Aspects of the Physical Geography of the Kano Region and Related Human Responses. Departmental Lecture Series 1: Kano, Dept, of Geog, BUK. 
Omogunloye O.G., Oladiboye O.E, Qaadri J.A. and Omogunloye H.B (2013). Geospatial Analysis and Distribution of Records of Sicknesses/Diseases (Malaria, Diabetes, Sickle Cell Disorder, Typhoid Fever) (A Case Study of the General Hospitals in Lagos State, Nigeria Journal of Medical and Applied Biosciences 5(1): 75-83

Onyido A.E, Ifeadi C.P, Umeanaeto P.U., Irikannu K.C, Aribodor D.N, Ezeanya L.C, Ugha C.N, Obiechina, I.O (2014). Co-Infection Of Malaria And Typhoid Fever In Ekwulumili Community Anambra State, Southeastern Nigeria New York Science Journal 7(7):18-27

Opara, A. U., Nnodim, J. K, Oluwafemi, B. E and Nwachukwu M. I(2011). Co-Infection of Malaria and Typhoid Fever among Patients in Owerri, Imo State, Nigeria, Global Research Journal Of Science 1: 5-8

Parikh, F. S. (2012): Management of Enteric Fever in 2012, Mumbai, Medicine Update 22: 12-14

Seljul, R. M., Ogundeko, Olugbenga, T., Isaiah, I. I., and Momoh, A. J. (2014): Use of stool culture as a determinant parameter of enteric fever in adults attending Bingham University Teaching Hospital Jos, Nigeria; Clinical Medicine Research 3(2): 31-35

Sharma N, Koju R, Karmacharya B, Tamang MD, Makaju R, Nepali N, Shrestha P, Adhikari D (2003). Typhoid fever in Dhulikhel hospital, Nepal, Kathmandu University. Medical Journal. 2(3,7): 188-192.

Shuaibu, M. B. (2010). Typhoid fever and Environment in Kano Metropolis. Unpublished Masters in Environmental Management
Dissertation submitted to the Department of Geography, Bayero University, Kano. 24-40

Singh. B. (2011): Symposium: Typhoid Fever Epidemiology, Journal, Indian Academy of Clinical Medicine 2(1,2): 11-12

Tran, H. H., Bjune, G., Nguyen, B. M., Rottingen, J. A., Grais, R. F. and Guerin, P. J. (2005): Risk factors associated with typhoid fever in Son La Province, northern Vietnam; Transactions of the Royal Society of Tropical Medicine and Hygiene 99: 819-826.

Udeze, A.O., Abdulrahman,F., Okonko, I.O. and Anibijuwon,I.I. (2010): Seroprevalence of Salmonella typhi and Salmonella paratyphi among the first year students of University of Ilorin, Ilorin Nigeria. Middle-East Journal of Scientific Research 6(3):257-262.

United Nations (2001): Implementation of the World Programme of Action for Youth to the Year 2000 and Beyond; UN General Assembly 56 Session 1-17

Uttah E. C., Osim S.E.,Etta H., Ogban E., and Okon, N. E. E.(2013). Four-year longitudinal assessment of the prevalence of typhoid fever among those attending the General Hospital Etinan, Nigeria, International Journal of Scientific and Research Publications 3(7): 1-4

Wang P. J.,Wang Y., Zang Jing ,Christakos G , Sun j, Liu x , Lu I, Fu x Shi yi and Li x (2013): Spatiotemporal Transmission and determinants of typhoid and paratyphiod fever in Hongsta District in Yunnan Province ,China; PLOS Neglected Tropical Diseases, 7(3): 